Afr. J. Trad. CAM (2007) 4 (2): 191- 198

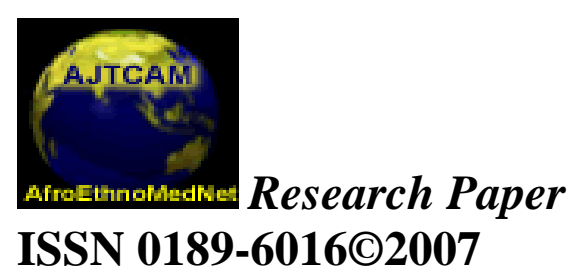
Afr. J. Traditional, Complementary and Alternative Medicines www.africanethnomedicines.net

\title{
MEDICINAL PLANTS USEFUL FOR MALARIA THERAPY IN OKEIGBO, ONDO STATE, SOUTHWEST NIGERIA.
}

\author{
${ }^{1 *}$ Tolu O. Odugbemi, ${ }^{2}$ Odunayo R. Akinsulire \\ ${ }^{1}$ Ibukun E. Aibinu and ${ }^{2}$ Peter O. Fabeku \\ ${ }^{1}$ Department of Medical Microbiology \& Parasitology, \\ College of Medicine, University of Lagos, P.M.B. 12003, Lagos \\ ${ }^{2}$ c/o St. Luke's Anglican Church, Okeigbo, Ondo State, Nigeria. \\ *E-mail: toluodugbemi@yahoo.com
}

\begin{abstract}
There is increasing resistance of malaria parasites to chloroquine, the cheapest and commonly used drug for malaria in Nigeria. Artemisin, a product from medicinal plant indigenous to China, based on active principle of Artemisia annua, has been introduced into the Nigerian market. However not much has been done to project antimalaria properties of indigenous medicinal plants. This study thus, has the main objective of presenting medicinal plants used for malaria therapy in Okeigbo, Ondo State, South west Nigeria. Focus group discussions and interview were held about plants often found useful for malaria therapy in the community. Fifty species (local names) including for example: Morinda lucida (Oruwo), Enantia chlorantha (Awopa), Alstonia boonei (Ahun), Azadirachta indica (Dongoyaro) and Khaya grandifoliola (Oganwo) plants were found to be in use for malaria therapy at Okeigbo, Southwest, Nigeria . The parts of plants used could either be the barks, roots, leaves or whole plants. The recipes also, could be a combination of various species of plants or plant parts. This study highlights potential sources for the development of new antimalarial drugs from indigenous medicinal plants found in Okeigbo, Nigeria.
\end{abstract}

Key words: $\quad$ Malaria, Medicinal plants, antimalarial drugs, Okeigbo, Southwest Nigeria.

\section{Introduction}

Malaria is a global disease that is predominant in the tropics and caused by blood parasites, Plasmodium falciparum, Plasmodium ovale, Plasmodium malariae and Plasmodium vivax. In Nigeria, malaria is mostly caused by $P$. falciparum and P. malariae. The female anopheles mosquito transmits these parasites to humans. Malaria has a great morbidity and mortality than any other infectious diseases of the world (World Malarial Report, 2005; Smith, 1978; WHO, 2000). Survey shows that $90 \%$ of the world's cases of malaria occur in sub-Saharan Africa. Nine out of ten cases of this disease occur in this region and record over one million deaths annually (World Malarial Report, 2005; Africa Union Memoir, 2005). High mortality rate is recorded in children and pregnant women (WHO, 2000), also the disease has negative impact on the economy of prevalent countries (African Summit on Roll Back Malaria, 2000; Abuja Malaria Summit, 2000).

In Nigeria, malaria is endemic throughout the country. World Health Organization (WHO) estimated malaria mortality rate for children under five in Nigeria at 729 per 100, 000. The Ministry of Health reported in April 2004 that malaria is responsible for one out of ten deaths in pregnant women and has caused the Federal Government of Nigeria over one billion Naira annually in treating malaria (Government in action, 2005). Medicinal plants have been used in the treatment and prevention of malaria in various parts of the world. Quinine extracted from the bark of the cinchona tree, was used as an antimalarial agent as early as 1632 (Baird et al., 1996) and by the $19^{\text {th }}$ century, it was still the only known antimalarial agent. Cinchona tree has been cultivated for this purpose all 


\section{Odugbemi et al., Afr. J. Trad. CAM (2007) 4 (2): 191 - 198}

over the world. Primaquine and quinacrine were produced after the first World War. Chloroquine followed shortly thereafter in 1934 (Thomson and Werbel, 1972 ), in 1946 it was designated the drug of choice for treatment of malaria (Coatney, 1963). It is known as the cheapest, and drug of choice for malaria treatment in Nigeria.

Recent surveys had shown the emergence of chloroquine - resistant strains of malaria parasites. In Africa, chloroquine resistant Plasmodium falciparum was first found in 1978 in nonimmune travellers from Kenya and Tanzania (Campbell et al., 1979; Fogh et al., 1979). This was followed 2 to 3 years later by reports from Madagascar (Aronson et al., 1981) Resistance spread from the African coastal areas inland and by 1983 had been observed in Sudan, Uganda Zambia and Malawi (Onori 1984; Ekue et al., 1983; Fogh et l., 1984; Slatter et al., 1983). The emergence of the ineffectiveness of chloroquine in combating malaria has led to additional studies, which had produced a new and effective antimalaria drug, Artemisin (World Malarial Report, 2005; Conference Report on the First International Meeting of the research initiative of Traditional Antimalaria Methods). The usefulness of this medicinal plant may hold the key to another new and effective antimalaria drug (UNESCO, 1998) in the future.

Indigenous medicinal plants in Nigeria used in combating malaria are yet to be projected in conferences as the foreign plants in spite of our rich flora diversity. Therefore, this present study has the main objective of presenting medicinal plants useful for malaria therapy in Okeigbo, Ondo State, Southwest of Nigeria.

\section{Materials and Methods}

This study was carried out in Okeigbo, Ondo State, Southwestern Nigeria. Okeigbo is a heterogeneous community, consisting of various groups of people from different parts of Southwest, Nigeria - Ife, Ifewara, Egbas, Owu, Offa, Ilorin, Ibadan, Ijebu, Ondo, Ilesha to mention a few and it is located at about 250km north of LagosState. This community has a single primary health care centre. The main occupations of the people are farming, teaching, hunting and petty trading. Some are also artisans, traditionalists and herbalists.

Focus group discussions and interviews were held with members of this community. Members involved in this study were mainly the traditional herbal chief (Asosanyin) who sees to the management and control of traditional practices of the use of herbs, traditional practitioners, herb sellers, primary and secondary school teachers, elderly members of the community 60 years and above; middle age members between the ages of 35-59 years old and health workers in the local Primary health centre.

Selections of these members were based on social status, occupation and those adjudged by the community to be knowledgeable in the ethno botanical uses of plants. Questions bothered on types and parts of plants often used for malaria therapy; methods for preparation and administration. Information on medicinal plants was compiled according to Generic name, family names, local names and parts of plants used. Collection of these plants cut across various locations in the community. Starting from the local garden at the back of houses, roadsides, farms, and mountain bases, secondary forest to primary forest. This was done with the aid of traditional practitioners.

Samples of plants collected were dried using absorbent paper, moistened with methylated spirit and mounted in accordance with conventional herbarium practice. Taxonomists in the Herbarium of Forestry Research Institute of Nigeria (FRIN), Ibadan, Oyo State led by Dr. G. Ugbogu and Mr. T.K. Odewo did scientific confirmation of some of the medicinal plants.

\section{Results}

Table 1 shows the list of medicinal plants often used for malaria therapy in Okeigbo, Ondo State, Nigeria. Table 2 shows medicinal plants that can be used alone in malaria therapy (monotherapy) while Table 3 shows plants used in combination of two, three, four, five or more different plants. Table 4 shows medicinal plants that are included as adjuncts in malaria herbal recipes, which are used as blood tonic or for clearing coated tongue (one of the symptoms of malaria). 
Odugbemi et al., Afr. J. Trad. CAM (2007) 4 (2): 191 - 198

Table 1: Medicinal plants that are used for malaria therapy in Okeigbo, Ondo state, southwest Nigeria

\begin{tabular}{|c|c|c|c|c|c|}
\hline S/No. & $\begin{array}{ll}\begin{array}{l}\text { Scientific } \\
\text { (Species) }\end{array} & \text { Name }\end{array}$ & Family Names & Local Names & $\begin{array}{l}\text { Common } \\
\text { Names }\end{array}$ & Parts Used \\
\hline 1. & $\begin{array}{l}\text { Sphenocentrum } \\
\text { jollyanum }\end{array}$ & Menispermaceae & Akerejupon & & Roots \\
\hline 2. & Rauvolfia vomitoria & Apocynaceae & Asofeyeje & & Roots, barks, leaves \\
\hline 3. & Enantia chlorantia & Annonaceae & $\begin{array}{l}\text { Osopa } \\
\text { Awopa } \\
\text { Dokita igbo }\end{array}$ & $\begin{array}{l}\text { African yellow } \\
\text { wood }\end{array}$ & Bark \\
\hline 4. & Khaya grandifoliola & Meliaceae & Oganwo & Mahogany & Bark \\
\hline 5. & Melicia excelsa & Moraceae & Iroko & Iroko & Root, Bark \\
\hline 6. & Senna siamea & Caesalpiniaceae & Kasia & Senna & Bark \\
\hline 7. & Senna podocarpa & Caesalpiniaceae & Asunwonibile & & Bark, leaves \\
\hline 8. & Azadirachta indica & Meliaceae & Dogonyaro & Neem & Bark, leaves \\
\hline 9. & Mangifera indica & Anacardiaceae & Mangoro & Mango & Bark, leaves \\
\hline 10. & Physalis angulata & Solanaceae & Koropo & & Leaves, whole plant \\
\hline 11. & Chromolaena odorata & Compositae & $\begin{array}{l}\text { Ewe Akintola } \\
\text { Ewe Awolowo }\end{array}$ & Siam weed & Root, leaves \\
\hline 12. & Carica papaya & Caricaceae & Ibepe & Pawpaw & Leaves, fruit \\
\hline 13. & Tithonia diversifolia & Compositae & $\begin{array}{l}\text { Jogbo } \\
\text { Agbale }\end{array}$ & Tree marigold & Leaves, stem twings \\
\hline 14. & Psidium guajava & Myrtaceae & Gilofa & Guava & Bark, leave \\
\hline 15. & $\begin{array}{l}\text { Lecaniodiscus } \\
\text { cupanioides }\end{array}$ & Sapindaceae & Akika & & Roots \\
\hline 16. & Curcuma longa & Zingiberaceae & Laali-pupa & Turmeric & Rhizome \\
\hline 17. & Zingiber officinale & Zingiberaceae & Ajo, Ata-ile & Ginger & Rhizome \\
\hline 18. & Nauclea latifolia & Rubiaceae & $\begin{array}{l}\text { Egberesi } \\
\text { Gberesi }\end{array}$ & African peach & Root, bark, leaves \\
\hline 19. & Citrus aurantifolia & Rutaceae & Osan wewe & Lime & $\begin{array}{l}\text { Root, bark, stem- } \\
\text { twigs, leaves, fruit }\end{array}$ \\
\hline 20. & Citrus aurantium & Rutaceae & $\begin{array}{l}\text { Osan- } \\
\text { ganinganin }\end{array}$ & Sour lime & $\begin{array}{l}\text { Root, bark, stem-twigs, } \\
\text { leaves, fruit. }\end{array}$ \\
\hline 21. & Citrus paradisi & Rutaceae & Osan gerepu & Grape & $\begin{array}{l}\text { Fruit, stem-twigs, } \\
\text { leaves, root }\end{array}$ \\
\hline 22. & Mondia whitei & Periplocaceae & Isirigun & & $\begin{array}{l}\text { Root, } \\
\text { whole plant }\end{array}$ \\
\hline 23. & Gossypium barbadense & Malvaceae & Owu & Cotton & Leaves \\
\hline 24. & Gossypium hirsutum & Malvaceae & Ela owu & Cotton & Leaves \\
\hline 25. & Alstonia boonei & Apocynaceae & Ahun & Stool wood & Root, bark, leaves. \\
\hline 26. & Parquetina nigrescens & Periplocaceae & Ogbo & & Whole plant, leaves \\
\hline 27. & Ananas comosus & Bromeliaceae & $\begin{array}{l}\text { Ope-Oyinbo } \\
\text { Ehin-ahun } \\
\text { Ekunkun }\end{array}$ & Pineapple & Unripe Fruit \\
\hline 28. & $\begin{array}{l}\text { Harungana } \\
\text { madagascariensis }\end{array}$ & Hypericaceae & Asunje & $\begin{array}{l}\text { Dragons blood } \\
\text { tree }\end{array}$ & Bark, leaves \\
\hline 29. & Funtumia africana & Apocynaceae & Ako-ire & Funtumia & Root \\
\hline 30. & Xylopia aethiopica & Annonaceae & $\begin{array}{l}\text { Erinje } \\
\text { Eeru }\end{array}$ & & Fruits, bark, leaves. \\
\hline 31. & Hyptis suaveolens & Labiatae & Jogbo & & Leaves \\
\hline
\end{tabular}




\begin{tabular}{|l|l|l|l|l|l|}
\hline 32. & $\begin{array}{l}\text { Acanthospermum } \\
\text { hispidum }\end{array}$ & Compositae & $\begin{array}{l}\text { Egungun- } \\
\text { arugbo }\end{array}$ & Starrburr & Leaves, whole plant. \\
\hline 33. & Morinda lucida & Rubiaceae & Oruwo & Brimstone tree & Bark, \\
leaves
\end{tabular}

Table 2: Medicinal plants that are used alone (not in combination) for malaria therapy in Okeigbo, Ondo state, Nigeria.

\begin{tabular}{|l|l|l|l|}
\hline S/No. & Botanical Names & Parts Used & Method of Extraction \\
\hline 1. & Nauclea latifolia & Bark, roots & Tincture, Decoction \\
\hline 2. & Morinda lucida & Roots, leaves & Tincture, infusion \\
\hline 3. & Enantia chlorantha & Bark & $\begin{array}{l}\text { Decoction, } \\
\text { infusion }\end{array}$ \\
\hline 4. & Alstonia boonei & $\begin{array}{l}\text { Infusion, } \\
\text { decoction. }\end{array}$ \\
\hline 5. & Curcuma longa & Bark & Tincture, \\
\hline 6. & Allium sativum & Rhizomecoction \\
\hline 7. & Carica papaya & Bulb & Concoction, tincture \\
\hline 8. & Tithonia diversifolia & Fruit, leaves & Infusion \\
\hline 9. & Azadirachta indica & Leaves & Infusion \\
\hline 10. & Vernonia amydalina & Bark, leaves & Decoction \\
\hline 11. & Rauvolfia vomitoria & Leaves & Infusion \\
\hline 12. & Funtumia africana & Root & Infusion \\
\hline 13. & Leconiodiscus cupanioides & Root & Infusion \\
\hline 14. & Khaya grandifoliola & Root & Infusion \\
\hline
\end{tabular}


Table 3: Medicinal plants that are used in combination in Okeigbo.

\begin{tabular}{|c|c|c|c|}
\hline Combination of two plants & Combination of three plants & Combination of four plants & Group of five or more plants \\
\hline 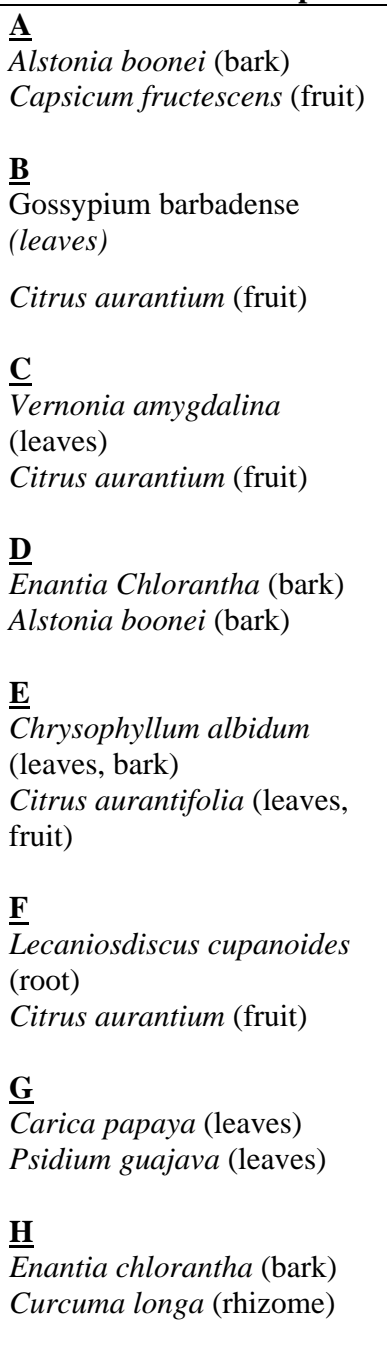 & 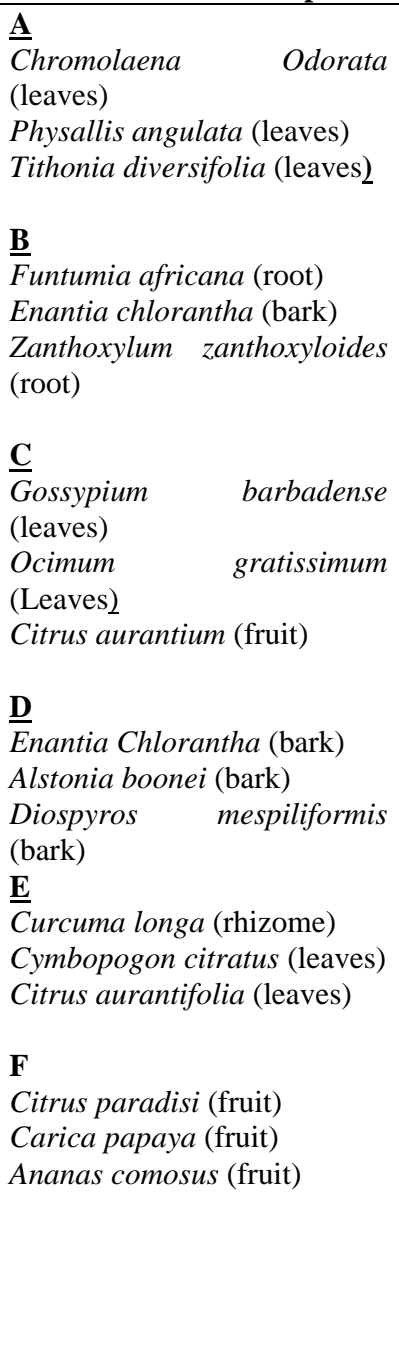 & $\begin{array}{l}\text { A } \\
\text { Vernonia amygdalina } \\
\text { (leaves) } \\
\text { Ocimum gratissimum } \\
\text { (Leaves) } \\
\text { Azadirachta indica (bark, } \\
\text { leaves) } \\
\text { Cymbopogon citratus (leaves) } \\
\text { B } \\
\text { Canna indica (leaves) } \\
\text { Citrus paradisi (fruit) } \\
\text { Ananas comosus (fruit) } \\
\text { Citrus aurantifolia (fruit) } \\
\text { C Alstonia boonei (bark) } \\
\text { Mangifera indica (bark, } \\
\text { leaves) } \\
\text { Psidium guajava (leaves) } \\
\text { Carica papaya (leaves) }\end{array}$ & $\begin{array}{l}\text { A } \\
\text { Harcuma longa (rhizome) } \\
\text { (bark, leaves) } \\
\text { Rauvolfia vomitoria (bark, } \\
\text { leaves) } \\
\text { Mangifera indica (bark, leaves) } \\
\text { Psidium guajava (bark, leaves) } \\
\text { Enanthia chlorantha (bark) } \\
\text { B } \\
\text { Sphenocentrum jollyanum (root) } \\
\text { Citrus aurantifolia (twigs, } \\
\text { leaves, fruit) } \\
\text { Cymbopogon citratus (leaves) } \\
\text { Lawsonia guineensis (leaves) } \\
\text { Carica papaya (root) } \\
\text { Citrus aurantium (fruit) } \\
\text { C } \\
\text { Citrus aurantifolia (leaves) } \\
\text { Chrysophyllum albidum (leaves) } \\
\text { Mangifera indica (bark, foliage } \\
\text { leaves) } \\
\text { Anarcadium occidentale (bark) } \\
\text { Sorghum bicolor (leaves, stem) } \\
\text { D } \\
\text { Ocimum gratissimum (Leaves) } \\
\text { Anarcadium occidentale (foliage } \\
\text { leaves) } \\
\text { Lecaniodiscus cupanioides } \\
\text { (foliage leaves) } \\
\text { Curcuma longa (foliage leaves) } \\
\text { Citrus aurantifolia (foliage } \\
\text { leaves) }\end{array}$ \\
\hline
\end{tabular}


Odugbemi et al., Afr. J. Trad. CAM (2007) 4 (2): 191 - 198

Table 4: Medicinal plants that are adjuncts included in malaria therapy recipes

\begin{tabular}{|l|l|l|}
\hline S/No. & Coated Tongue & Blood Supplement \\
\hline 1. & Heliotropicum indicum (Leaves) & Sorghum bicolor (Shoot) \\
\hline 2. & Chrysophyllum albidum (Bark) & Parquetina nigrescens (Leaves) \\
\hline 3. & Solanum nigrum (Leaves) & Khaya grandifoliola (Bark) \\
\hline 4. & Pycanthus angolensis (Bark) & \\
\hline 5. & Anacardium occidentale (Bark) & \\
\hline 6. & Mangifera indica (Bark, Leaves) & \\
\hline 7. & Khaya grandifoliola (Bark). & \\
\hline
\end{tabular}

\section{Discussion}

From the array of medicinal plants used for malaria therapy in Oke-Igbo, Ondo-State, this study has shown that indigenous medicinal plants exist, that can be exploited in the development of new antimalarial drugs. (Table 1). These plants are similar to those used for malaria therapy in Ghana (UNESCO, 1997), Sierra Leone (Agbovie et al., 2002) and agree with the work of Oliver (Barnish and Samai, 1992) and Singha (Oliver, 1960) on medicinal plants of Nigeria.

In preparation of herb recipes for malaria therapy, single plants (monotherapy) can be used (Table 2) or in combination of more than one plant (table 3). The combination of these different plants is claimed to cure several ailments and dysfunctions associated with malaria in the body. For instance, plants claimed to cure coated tongue and those that replenish blood cells during malaria attack are included in herbal recipes for malaria as shown in Table 4. They are also regarded as plants useful for malaria therapy. The treatment is observed to be traditional with deep socio-cultural expression as recognized by WHO, 1978).

Significantly, majority of these plants when prepared are very bitter in taste. More so, it is believed that each active principle of component parts making up the recipe complement one another in the fight against malaria parasite. Further studies would be required to explain this activity among component parts of malaria recipes.

Furthermore, selections of these component parts are often based on the severity of the disease. The active principle of these plants are often extracted through, infusion, decoction and tincture (Taylor, 2004). However, component of different herbal recipes in this study differ along lineage, class, cultural group, occupation, status and age group, suggesting the pluralistic and diverse nature of traditional medicine (Singha, 1965). In addition, during administration of these drugs, recipes that are considered to be very potent are required to be taken in little quantity to avoid side effects like stomach disorders.

Consequently, the ability of people, encountered in the course of this study, in giving at least an herbal prescription for malaria shows the prevalence of the disease and how it has been tackled over time. Therefore, these findings suggest that medicinal plants used for malaria therapy in Okeigbo, Ondo State, Nigeria are potential sources for the development of new antimalarial drugs from indigenous plants in Nigeria.

\section{Conclusion}

This study has attempted to highlight medicinal plant claimed to be used or associated with malaria therapy in the indigenous Yoruba community as prescribed or suggested by individuals or groups in Okeigbo, Southwest, Nigeria. These medicinal plants may probably contain yet undiscovered anti-malarial properties, which can serve as a template for the production of cheap anti-malaria drug from indigenous plants in Nigeria. There is a need for a multidisciplinary approach to develop potentially effective drugs while noting dangerous drugs and practices that should be discarded.

\section{Conflicts of interest statement}

The authors do not have conflicts of interest concerning the medicinal plants work reported in this paper. 


\section{Odugbemi et al., Afr. J. Trad. CAM (2007) 4 (2): 191 - 198}

\section{Acknowledgements}

This study was supported by a grant from University of Lagos (CRC 2005/08). We are grateful to Chief Damilola Ogungbemi the Aso-Osanyin of Okeigbo land for his support and contribution on herbal recipes. Mrs. Ranti Adetoro of Okeigbo also provided useful suggestions of recipes of antimalarial drugs in Okeigbo. We appreciate the assistance of members of staff of the Herbarium Department of Forestry Research Institute of Nigeria (FRIN), in particular the head of department Dr. G. Ugbogu in confirming the identity of some plants. The secretarial assistance of Mr. O.E. Okon of the College of Medicine, University of Lagos is gratefully acknowledged.

\section{References}

1) Abuja Malaria Summit (2000). Available on: J. /Div. Data/Abuja Malaria Summit/Abjbint2. doc.

2) Africa Union Memoir (2005). "Unite against Malaria, together we can beat malaria” on African Malaria Control Day.World Malarial Report (2005). Information available to WHO and UNICEF at the end of 2004.

3) African Summit on Roll Back Malaria (2000). Summit on Roll Back Malaria Abuja, Nigeria. Abuja Malsum Intbrief 2: 02 March

4) Agbovie, T., Amponsah, K., Crentsil O’R, Dennis, F., Odamtta GT., and Ofusohene-Djan W (2002). Conservation and Sustainable Use of Medicinal Plants in Ghana. Ethnobotanical Survey. From the Information Officer, UNEP-WCMC, 219 Huntingdon Rd, Cambridge CB 30DL, UK.

5) Aronson, B., Bengsston, E., Bjorkman, A., Pehrson, PO., Rombo, L. and Wahlgren, M. (1981). Chloroquine-resistant falciparum malaria in Madasgar and Kenya. Annals Trop. Med. Parasitol. 75:367373.

6) Baird, J. K., Caneta-Miguel, E., Masba, S., Bustos, D. G., Abrenica, J. A., Layawen, A. V., Calulut, J. M., Leksana, B. and Wignall, F. S. (1996). Survey of resistance to chloroquine of falciparum and vivax malaria in Palawan, The Philippines. Trans. Roy. Soc. Trop. Med. Hyg. 90:413-414.

7) Barnish, G. and Samai, S. K. (1992). Some medicinal plant recipes of the Mende, Sierra Leone Text from Medical research Council Laboratory, Sierra Leone.

8) Campbell CC, Chin W, Collins WE, Teutsch SM, Moss DM (1979). Chloroquine-resistant Plasmodium falciparum from East-Africa:cultivation and drug sensitivity of the Tanzanian I/CDC strain from an American tourist. Lancet, ii: 1151-1154.

9) Coatney GR. (1963) Pitfalls in a discovery: the chronicle of chloroquine. The American Journal of Tropical Medicine and Hygiene. 12:121-128.

10) Conference Report on the First International Meeting of the research initiative of Traditional Antimalaria Methods (1999). Conference Report on the First International Meeting of the research initiative of Traditional Antimalaria Methods held at Tumaini Unversity of. Health Science. Mosni. Tanzania.

11) Ekue JM, Ulrich AM, Njelesani EK (1983). Plasmodium malaria resistant to chloroquine in a Zambian living in Zambia. British Medical Journal (Clinical Research Ed.). 286:1315-1316

12) Fogh S, Jepsen S, Mataya RH (1984). R-III Chloroquine-resistant Plasmodium falciparum malaria from Northern Malawi. Transactions of the Royal Society of Tropical Medicine and Hygiene 78:282.

13) Fogh S, Jepsen S, and Effersoe P (1979). Chloroquine-resistant Plasmodium falciparum malaria in Kenya. Transactions of the Royal Society of Tropical Medicine and Hygiene. 73:228-229.

14) Government in action (2005). Report from presidential research and communication unit, office of public communication, State House, Abuja.

15) Oliver B (1960). Medicinal Plants in Nigeria. Published By the College of Arts; Science and Technology, 1960.

16) Onori E (1984). The problem of Plasmodium falciparum drug resistance in Africa south of the Sahara. Bull. World Health Organization. 62(Suppl.):55-62

17) Singha SC. (1965) Medicinal Plants in Nigeria. Published by the Nigerian National Press Ltd., Apapa, Lagos, Nigeria

18) Slatter MJ, Pettengell JK, Taylor RK (1983). Chloroquine-resistant malaria. South African Medical Journal. 63:838.

19) Smith AL (1978). Text on Microbiology and Pathology Eleventh edition, Published by CV Mosby Com. USA. 
Odugbemi et al., Afr. J. Trad. CAM (2007) 4 (2): 191 - 198

20) Taylor, L (2004). The Healing Power of Rainforest Herbs. Square one Publishers, Inc.

21) Thomson PE and Werbel LM (1972). Antimalarial agents: chemistry and pharmacology. In G. de Stevens (ed.), Medicinal chemistry. Academic Press, Inc., New York, N.Y.

22) United Nations Educational Scientific and Cultural Organization (UNESCO) (1998). Terminal Report. Promotion of Ethnobotany and sustainable use of plant resources in Africa. Pg.60, Paris.

23) United Nations Educational Scientific and Cultural Organization UNESCO (1997). Culture and health, orientation texts. World decade for cultural dev. 1988-1997. Doc. CLT/DEC/PRO, Paris, France, Pg.129.

24) WHO (2000). Press release on African Summit on Roll back Malaria.

25) World Health Organization (WHO) (1978). "The promotion and development of traditional medicine". Technical Report Series. 622, WHO, Geneva.

26) World Malarial Report (2005). Information available to WHO and UNICEF at the end of 2004. 